\title{
Tree plantations are hot-spots of plant invasion in a landscape with heterogeneous land-use
}

\author{
Anikó Csecserits*, Zoltán Botta-Dukát, György Kröel-Dulay, Barbara Lhotsky, \\ Gábor Ónodi, Tamás Rédei, Katalin Szitár, Melinda Halassy
}

MTA Centre for Ecological Research, Institute of Ecology and Botany, Alkotmány út 2-4., 2163 Vácrátót, Hungary

\section{A R T I C L E I N F O}

\section{Article history:}

Received 16 April 2015

Received in revised form 9 December 2015

Accepted 14 March 2016

Available online xxx

\section{Keywords:}

Level of invasion

Land-use change

Neophyte

Semi-natural forest

Semi-natural grassland

\begin{abstract}
A B S T R A C T
Invasion of alien plant species is one of the main reasons for biodiversity loss in terrestrial ecosystems. However, alien plant species are not evenly distributed in the landscape. We studied which factors determine the actual level of neophyte invasion in a landscape with heterogeneous land-use and which habitats are the most infected. Since neophyte species with different life-forms can respond differently to the factors determining the invasion, species groups of annual, herbaceous perennial and woody neophytes were also analyzed separately.

The study was conducted within the field site network of the Kiskun-LTER program (Hungary), in 16 sites of $5 \mathrm{~km} \times 5 \mathrm{~km}$. Fifteen habitat types were distinguished belonging to five major land-use/land cover types (agricultural land, abandoned agricultural land, tree plantation, semi-natural grassland and semi-natural forest). Present and past land-use, landscape composition and environmental variables were included as factors with a potential impact on the level of invasion.

The most important factor determining invasion level was present habitat type, followed by the past habitat type of the location and landscape context. Tree plantations, agricultural habitats and recently abandoned agricultural habitats had the highest level of invasion.

As expected, annual neophytes were most abundant in agricultural habitats, while perennial herbaceous neophytes were most abundant in old-fields and plantations, and woody neophytes in tree plantations. Past agricultural land-use was reflected in the higher levels of invasion of annuals and perennials, and past forestry practice resulted in higher levels of invasion of woody neophytes. In a landscape with a higher proportion of tree plantations, not only the tree plantations, but primary woodland patches also showed higher levels of invasion by woody neophyte species.

Our results indicate the importance of present and past land-use in plant invasion and suggest that tree plantations are hot-spots of plant invasion and threaten the remnants of semi-natural vegetation.
\end{abstract}

(c) 2016 Elsevier B.V. All rights reserved.

\section{Introduction}

Land-use change and invasion of alien species are two major drivers responsible for recent biodiversity loss in terrestrial ecosystems (Hobbs, 2000; Sala et al., 2000). The problem caused by alien invasion is often related to changes in land-use (Hobbs, 2000; Vilà et al., 2006, 2009): land-use influences the invasion process by creating and supporting optimal habitats for invaders and by enhancing actual propagule pressure through landscape compositional changes (Vilà and Ibáñez, 2011).

\footnotetext{
* Corresponding author.

E-mail address: csecserits.aniko@okologia.mta.hu (A. Csecserits).
}

The level of invasion is defined as the number or proportion of alien species in a given habitat (Catford et al., 2012; Richardson and Pyšek, 2006). Comparison of habitats across regions revealed that habitats differ considerably in the level of invasion, and differences are consistent across different regions (Chytrý et al., 2008b). The level of invasion seems to depend more on the inherent properties of habitats (invasibility), than on the actual propagule pressure or the geographic location (Chytrý et al., 2008b). Habitats associated with high invasion levels are generally characterized by a fluctuating availability of resources either as a result of natural fluctuations (e.g. floodplains) or due to anthropogenic disturbance (Chytrý et al., 2008a, 2008b; Davis et al., 2000; Pyšek and Chytrý, 2014). Disturbed and intensively managed habitats support the highest levels of invasion both at the local (Chytrý et al., 2005; González-Moreno et al., 2014; Jauni and Hyvönen, 2010; Vilà et al. 
2007; Walter et al., 2005), and regional scales (Chytrý et al., 2008b, 2009).

Land-use and its change directly influence alien invasion through the alteration of habitat types (Hobbs, 2000). Beside the direct effect of changing habitat type, the indirect effects of landuse, such as landscape configuration and historical land-uses can be important in the invasion process (Vilà and Ibáñez, 2011). Therefore, these factors should also be taken into account when land-use planning and management decisions are made to control alien species (Cole et al., 2007; Thomas and Moloney, 2015). The landscape configuration can be an important factor determining the presence of alien species compared to local scale factors that have greater effect on species abundance (Vilà and Ibáñez, 2011). The main drivers from landscape configuration resulting in increased levels of invasion are: increasing fragmentation and decreasing habitat connectivity; intensification of land-use such as agriculture; urbanization; and the development of transport networks (Hobbs, 2000). The temporal sequence of land-use change can have diverse impact on invasion. For example, the type of land-use at the time of introduction of a given alien species, along with the direction of the land-use change (i.e. increasing or decreasing intensity of human disturbance) can have important effects (Vilà and Ibáñez, 2011).

Different groups of invasive species might respond differently to land-use change. For example species with a longer history of invasion in a given country (e.g. archaeophytes) depend more on the habitat type than recently arrived species (Pyšek and Chytrý, 2014; Vicente et al., 2014). This is probably due to their adaptation to agricultural management (Jauni and Hyvönen, 2010). Neophyte species having a shorter history of adaptation to the new environment and depend more on continuous propagule pressure (Chytrý et al., 2008b; Pyšek and Jarošík, 2005). Alien species belonging to different life forms, trophic levels or functional groups might induce different changes in the ecosystem structure or function. The establishment and expansion of different invasive groups (e.g. annuals, perennial herbs and woody species) might be a good indicator of invasion pathways and processes (Catford et al., 2012; Gassó et al., 2012; Thuiller et al., 2006).

Hungary, situated in a transitional biogeographic zone between deciduous forest and the forest steppe (Magyari et al., 2010;
Zólyomi, 1974), has significant biodiversity, but also a high diversity of alien species. The number of recognized neophyte plant species was 715 in 2004 (Balogh et al., 2004). The problem of invasion is coupled with human landscape change (Török et al., 2003). In the Kiskunság region the landscape has been altered significantly: primary or secondary grasslands were transformed to tree plantations or arable lands while arable lands have been transformed to secondary grasslands or tree plantations. By the 21 st century, almost fifty percent of 18 th century open sand grasslands have been replaced by tree plantations (Biró et al., 2013). The present landscape is dominated by agricultural land, semi-natural grasslands and non-native tree plantations, resulting in a heterogeneous land-use pattern (Biró et al., 2013; Rédei et al., 2008; Rédei et al., 2011). Given the relatively homogeneous climatic conditions in the study area and the presumably uniform regional alien species pool, we hypothesize that the level of invasion would reflect the effect of present and past land-use. Our questions are:

1. What factors determine the level of neophyte invasion in a landscape with heterogeneous land-use?

2. Which habitat types are the hot-spots of plant invasion in this landscape?

3. Is there a difference in the factors that determine the invasion level of annual, perennial herbaceous and woody neophytes?

\section{Materials and methods}

\subsection{Study area and sampling design}

The study was conducted in the Kiskunság inland sand dune area, which extends to $7500 \mathrm{~km}^{2}$, in the centre of the Pannonian biogeographic region. The climate of the region is moderately continental with a sub-Mediterranean influence. The landscape consists of the remnants of the forest steppe vegetation (Fekete et al., 2014; Magyari et al., 2010; Zólyomi, 1974) and cultivated land with changing land-use patterns (Biró et al., 2013; Csatári and Farkas, 2008). For more details on the study area see Csecserits et al. (2011) and Rédei et al. (2014).

Table 1

Overview of habitat types used in this study and their correspondence with the European Nature Information System (EUNIS).

\begin{tabular}{|c|c|c|c|}
\hline Habitat name & Habitat codes & Number of relevés & EUNIS code \\
\hline \multicolumn{4}{|l|}{ agricultural habitat } \\
\hline croplands & AC & 46 & I1 \\
\hline vineyards and orchards & AV & 29 & G1.D \\
\hline \multicolumn{4}{|l|}{ abandoned agricultural habitat } \\
\hline old-fields abandoned 1-7 years ago & 01 & 35 & E5.1 \\
\hline old-fields abandoned 8-20 years ago & $\mathrm{O} 2$ & 42 & E5.1 \\
\hline old-fields abandoned 21-57 years ago & 03 & 40 & E5.1 \\
\hline \multicolumn{4}{|l|}{ tree plantation } \\
\hline locust (black) & PL & 44 & G1C3 \\
\hline pine (black and Scot) & $\mathrm{PP}$ & 47 & G3F2 \\
\hline native white and grey poplar & PN & 39 & $\mathrm{G} 1 \mathrm{C} 1$ \\
\hline exotic poplar & $\mathrm{PE}$ & 19 & G1C1 \\
\hline oak & PO & 17 & G1C4 \\
\hline young plantations & PY & 41 & G5.7 \\
\hline \multicolumn{4}{|l|}{ semi-natural grassland } \\
\hline open grasslands & GO & 37 & E1.994 \\
\hline closed grasslands & GC & 46 & E1.995 \\
\hline \multicolumn{4}{|l|}{ semi-natural woodland } \\
\hline open woodlands & WO & 37 & G1.7A1 \\
\hline closed woodlands & WC & 36 & G1.7A1 \\
\hline
\end{tabular}


Sampling was carried out within the field site network of the Kiskun-LTER program, which consists of 16 sites, of $5 \mathrm{~km} \times 5 \mathrm{~km}$ each, representing all major land-use/land cover types characteristic to the region (agricultural land, abandoned agricultural land, tree plantation, semi-natural grassland, and forest) in varying proportions (Csecserits et al., 2011; Rédei et al., 2008, 2011).

We distinguished and sampled 15 habitat types in five land-use categories (Table 1.) The abbreviation of the habitat types and the number of the sampled plots are in the brackets.

Agricultural fields included regularly ploughed annual and perennial croplands ( $A C, n=46)$, vineyards and orchards (AV, $\mathrm{n}=29$ ).

Old-fields were categorized into three age groups based on historical aerial photographs: old-fields abandoned 1-7 years before sampling $(01, n=35)$, old-fields abandoned 8-20 years before sampling $(02, n=42)$, and old-fields abandoned $21-57$ years before sampling $(03, n=40)$.

Tree plantations which were at least 20 years old at the start of sampling, were categorized into the following types: black locust (Robinia pseudoacacia) (PL, $\mathrm{n}=44$ ), black and Scots pine (Pinus nigra and Pinus sylvestris) (PP, $\mathrm{n}=47$ ), exotic poplar (Populus $x$ euramericana) ( $\mathrm{PE}, \mathrm{n}=19$ ), native white and grey poplar (Populus alba and $P . x$ canescens) $(\mathrm{PN}, \mathrm{n}=39)$, pedunculate oak (Quercus robur) ( $\mathrm{PO}, \mathrm{n}=17$ ). Young ( $<3$ years old) tree plantations ( $\mathrm{PY}$, $\mathrm{n}=41$ ) were also sampled.

We sampled the four habitat types of the semi-natural foreststeppe mosaic: open grassland, closed grassland, open woodland and closed woodland. Open grasslands are dominated by Festuca vaginata and Stipa borysthenica and the total vascular plant canopy cover is less than $50 \%(\mathrm{GO}, \mathrm{n}=37)$. Closed grasslands are dominated by Festuca $\times$ wagneri, Stipa capillata and Bothriochloa ischaemum and canopy cover is more than $80 \%(\mathrm{GC}, \mathrm{n}=46)$. Open woodlands are dominated by Quercus robur, Populus alba and Juniperus communis (WO, $\mathrm{n}=37$ ); and closed woodlands are dominated by Quercus robur and Populus alba (WC, $\mathrm{n}=36$ ). Open and closed woodlands differ significantly in character. Open woodlands are characterized by a less developed tree canopy layer, a dense shrub layer and patches of grassland, whilst closed woodlands have no patches of grassland and the shrub layer is scarce due to the more developed tree canopy.

We aimed at sampling three stands of the 15 selected habitat types within each study site (Fig. 1) using a spatially stratified random design. Separate stands of a given habitat within a site were sampled or, in case of large homogenous habitats, sampled stands were at least $300 \mathrm{~m}$ from each other. The total number of stands was 555, because not all habitat types were present in each site or not in three separate stands. In each stand, we visually estimated the aboveground percentage cover of all vascular plant species in a $20 \mathrm{~m} \times 20 \mathrm{~m}$ plot. To avoid edge effect, plots were not placed within $10 \mathrm{~m}$ from the stand boundary. Vegetation surveys were carried out in June-August, 2006-2008. Nomenclature follows that of Király (2009).

\subsection{Studied species groups}

In this paper we present data on neophyte species defined as species that arrived in the Carpathian Basin after 1500 (Pyšek, 1995; Pyšek et al., 2004), which were selected based on the list of Hungarian neophytes published by Balogh et al. (2004) and Király (2009). Since the distinction between archaeophyte and native status is unclear for several species within Hungary, we excluded archaeophytes from the analysis. In case of certain neophyte species (e.g. black locust and black pine) a distinction was made between spontaneous presence and obviously planted presence,

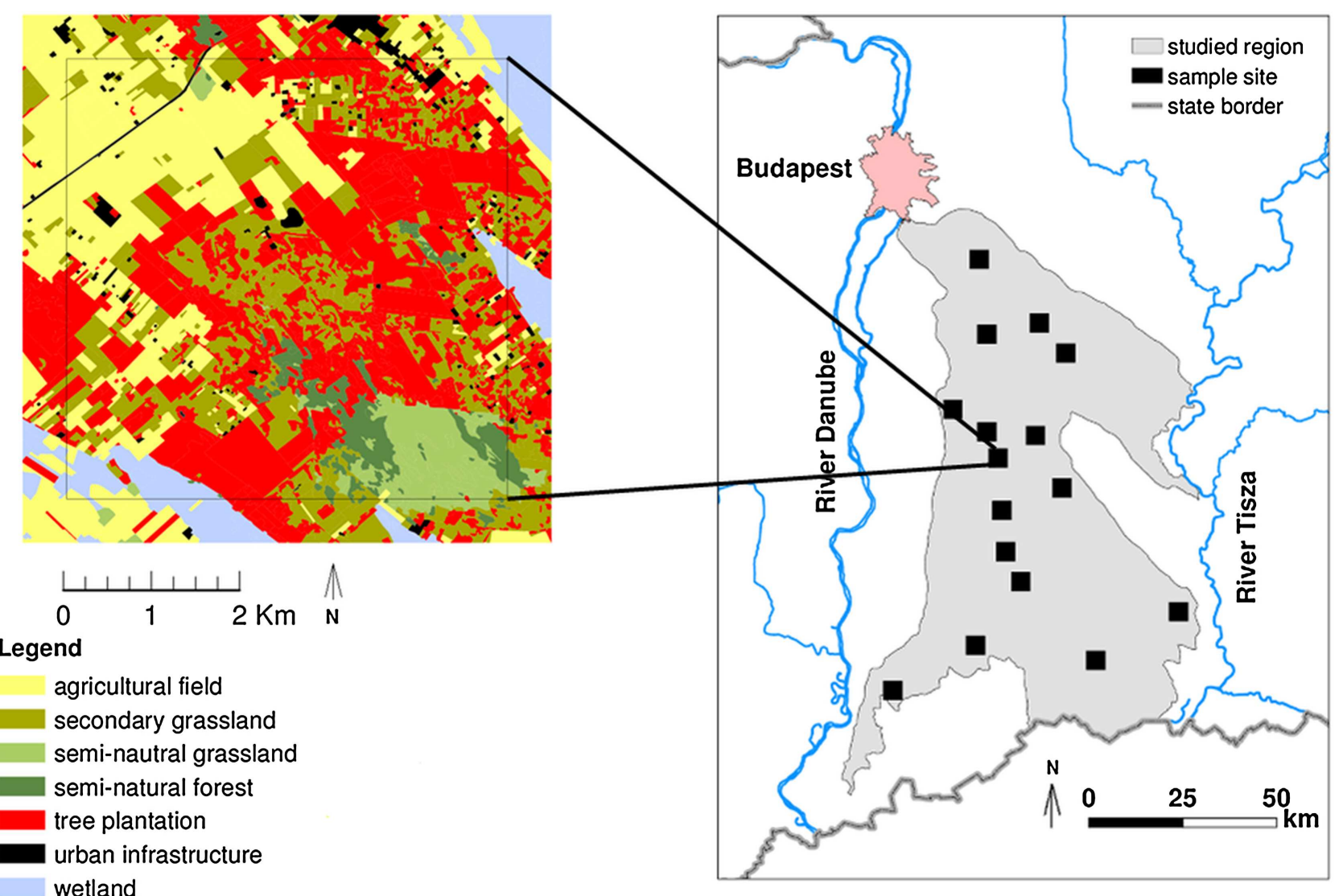

Fig. 1. Map of the study area with the 16 sampling sites and the habitat map of one $5 \mathrm{~km} \times 5 \mathrm{~km}$ study site (Orgovány) from 2005 . 
and only the spontaneous occurrences were used in the analyses. Moreover, we distinguished three growth forms: annual, perennial herbaceous and woody neophyte species on the basis of Király (2009) for a better understanding of invasion patterns.

Five indicators were selected to study the invasion level of different habitats in the region: (1) the relative species richness of neophyte species (measured as the number of neophyte species in proportion to all species found in the plot), (2) the relative cover of neophyte species, and (3) the relative cover of annual, (4) herbaceous perennial and (5) woody neophyte species. All were measured as the proportion of the cover of the given group of neophytes compared to the total vascular cover per plot.

\subsection{Environmental predictors}

In order to fit sensible models for the invasion level of the studied region, factors describing the present landscape context, present and past habitat type, and the local environment were included in the analysis (Table 2). The present landscape context was described with the proportional area of different habitat types within $500 \mathrm{~m}$ around each sampling plot. A $500 \mathrm{~m}$ radius was selected because the propagule pressure is strongest within a few hundred meters of the source and it declines rapidly with distance (Rouget and Richardson, 2003). Five habitat categories were distinguished in this case corresponding to the major land cover types in the region: agricultural land, abandoned field where secondary grasslands developed, tree plantation, semi-natural grassland, and semi-natural forest. Habitat maps were made on the basis of aerial photos from 2005 with ArcGis 9.2 software (ESRI, 2006).

The past habitat type of each sampling plot was described on the basis of aerial photos from the years 1950-1952 and 19861989. For the period 1986-1989, the same five land-use/land cover categories were used as for 2005. As for the 1950s, it was impossible to distinguish between semi-natural and secondary grassland (probably because there was no secondary grassland, Biró et al., 2013), therefore these two categories were merged resulting in four different land-use categories: agricultural land, tree plantation, grassland, and semi-natural forest.

In addition, the distance from the nearest agricultural field based on the habitat maps from 2005 and the distance from the nearest local road were calculated for each sampling plot as proxies for human land-use intensity and for the propagule pressure of neophyte species (Vilà and Ibáñez, 2011).

The local environment was characterized by two climatic variables (annual precipitation and mean annual temperature), by descriptors of locality (elevation, slope, and aspect) and by soil data. The aspect value was transformed from the circular aspect variable into a linearized form ranging from zero to one according to Somodi et al. (2010). Annual precipitation was derived from interpolated climatic data from 1961 to 1990 from the Hungarian Meteorological Service (HMS 2001), whereas temperature data

Table 2

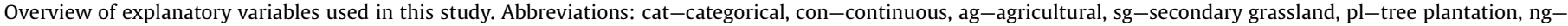
semi-natural grassland, $\mathrm{nf}-$ semi-natural forest.

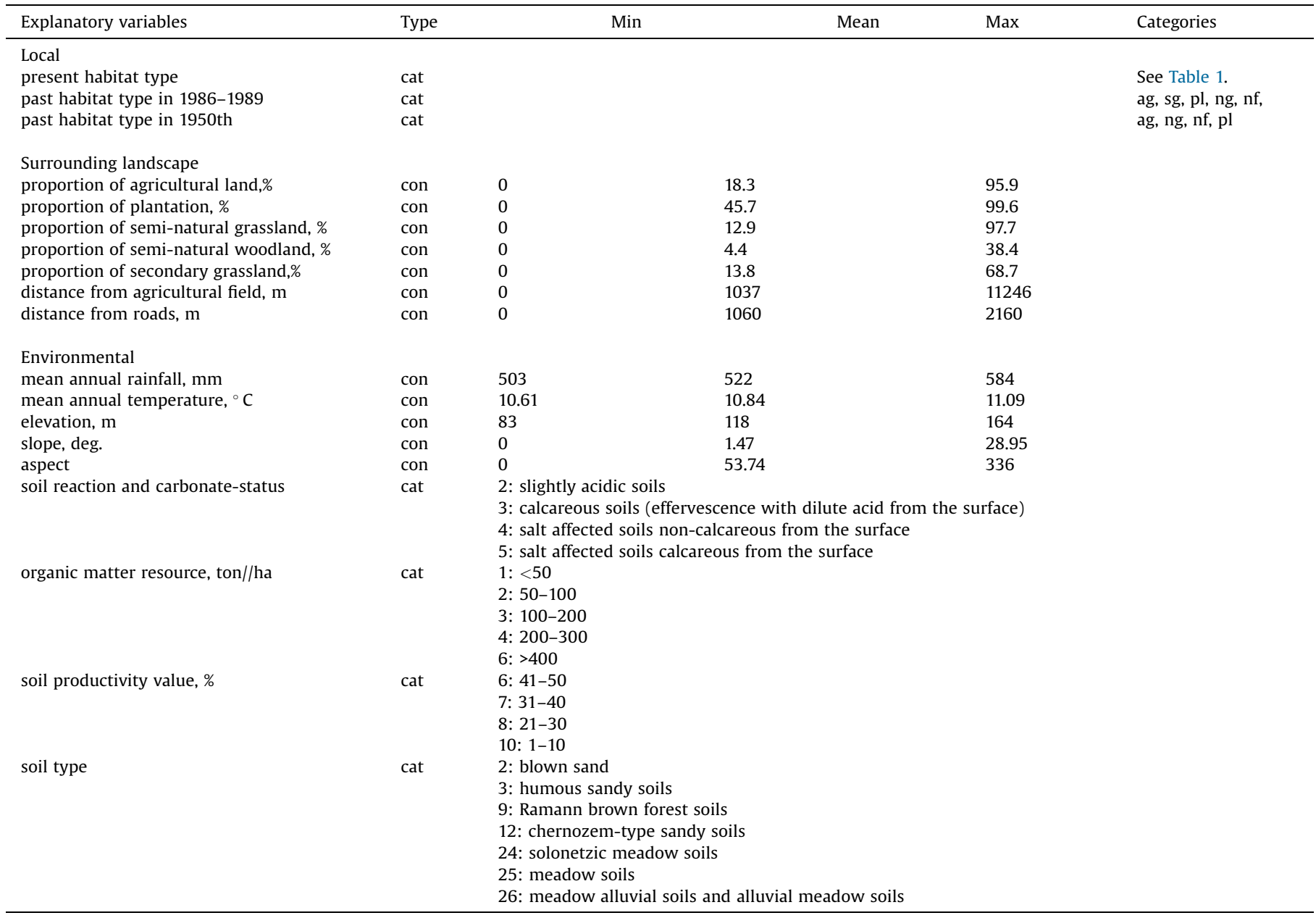


from the WORLDCLIM database (Hijmans et al., 2005) was used. Descriptors of locality were derived from the digital elevation map (DEM) of the sampling sites. Data connected to soil properties, namely chemical reaction, organic content, soil productivity and soil type was obtained from the database (AGROTOPO, 1994).

Beside these environmental variables, the composition of native communities at plot level was included in the analysis. To avoid the artefacts due to mathematical constraints, we did not use all of the possible combinations. When analysing the relative species richness of neophyte species, we used the cover of nonalien species, non-alien herbs, shrubs and trees together, and the cover of trees. When analysing the relative cover of annual and herbaceous perennial neophyte species, we used the cover of shrubs and trees together and the cover of trees.

\subsection{Data analysis}

To explore the relationship between the level of invasion and the predictor variables, conditional inference-based decision trees were fitted to the data. Decision trees (also known as classification and regression trees; Breiman et al., 1984) are non-parametric statistical methods that can handle nonlinear relationships, very large sets of mixed type (i.e. both categorical and continuous) predictors, and the results are easy to interpret and indicate the variable that significantly discriminates between classes (Crawley, 2007). Furthermore, as they handle the predictors one by one, they are essentially free from problems caused by multicollinearity. The selected algorithm offers unbiased variable selection and a statistically sound stopping rule (Hothorn et al., 2006), which eliminates the variable selection bias and problems of under- and over-fitting. Decision tree models are frequently used to study the distribution of invasive organisms (e.g. Usio et al., 2006; Hejda et al., 2009; Pyšek et al., 2010; Pinke et al., 2011).
For each fitted tree, explained variance $\left(\mathrm{R}^{2}\right)$ was calculated using the standard formula. Spatial autocorrelation of model residuals were checked by calculating Moran's I correlogram (Bjornstad and Falck, 2001): there were no significant spatial autocorrelation for either model. All analysis were done in $\mathrm{R}$ 3.1.1 environment ( $\mathrm{R}$ Core Team, 2014) using party and ncf (Bjornstad, 2013) packages.

\section{Results}

We found a total of 47 neophyte species, including 21 annuals, 9 herbaceous perennials and 17 woody neophyte species (App. A).

The fitted regression tree for the relative species richness of neophyte species explained $59.1 \%$ of the total variance and present habitat type was the most important predictor variable (Fig. 2). In the first split, agricultural fields, youngest old-fields and plantations were separated from semi-natural habitats and elder oldfields, because of the higher proportion of neophyte species in the first group. This first group was further divided to agricultural fields and young plantation associated with higher proportion of neophyte species (median: $26.09 \%$ and $38.44 \%$ on the last two branches) and to young old-fields and other plantation with lower relative richness (median: $16.17 \%$ and $21.74 \%$ on the last two branches). In the case of the second group, i.e. right branch, closed forests and old-fields had larger proportion of neophyte species (median $13.59 \%$ and $8.76 \%$ on the last two branches) than open forests, closed and open grasslands (median $5.66 \%$ and $2.82 \%$ on the last two branches).

For the relative cover of neophyte species the regression tree explained $27.6 \%$ of the total variance. The first splitting variable was the present habitat type (Fig. 3). The highest relative cover could be observed in agricultural fields, old-fields, young plantations and poplar plantations (median: 22.66\%). The right

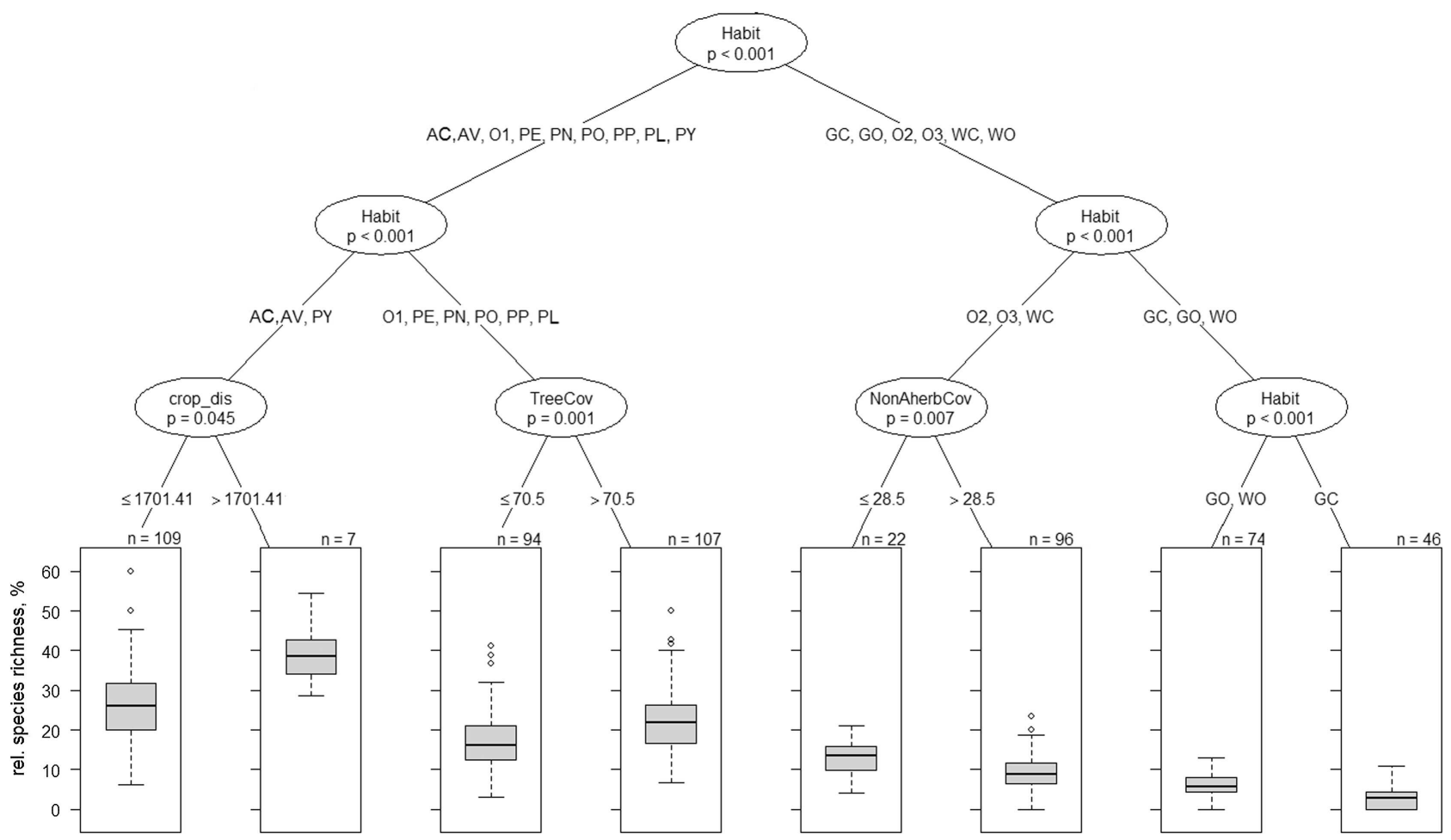

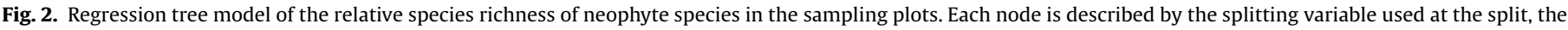

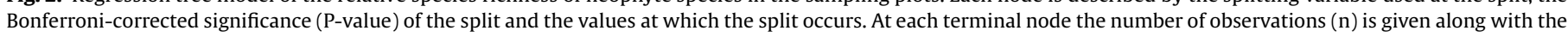

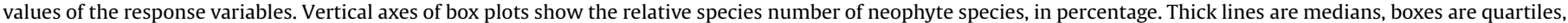

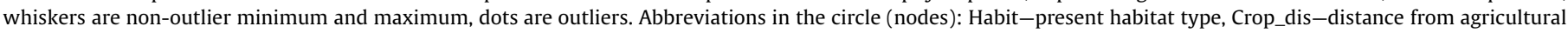
field, m, TreeCov-cover of trees, NonAherbCov-cover of non-alien herb. For habitat codes see Table 1. 


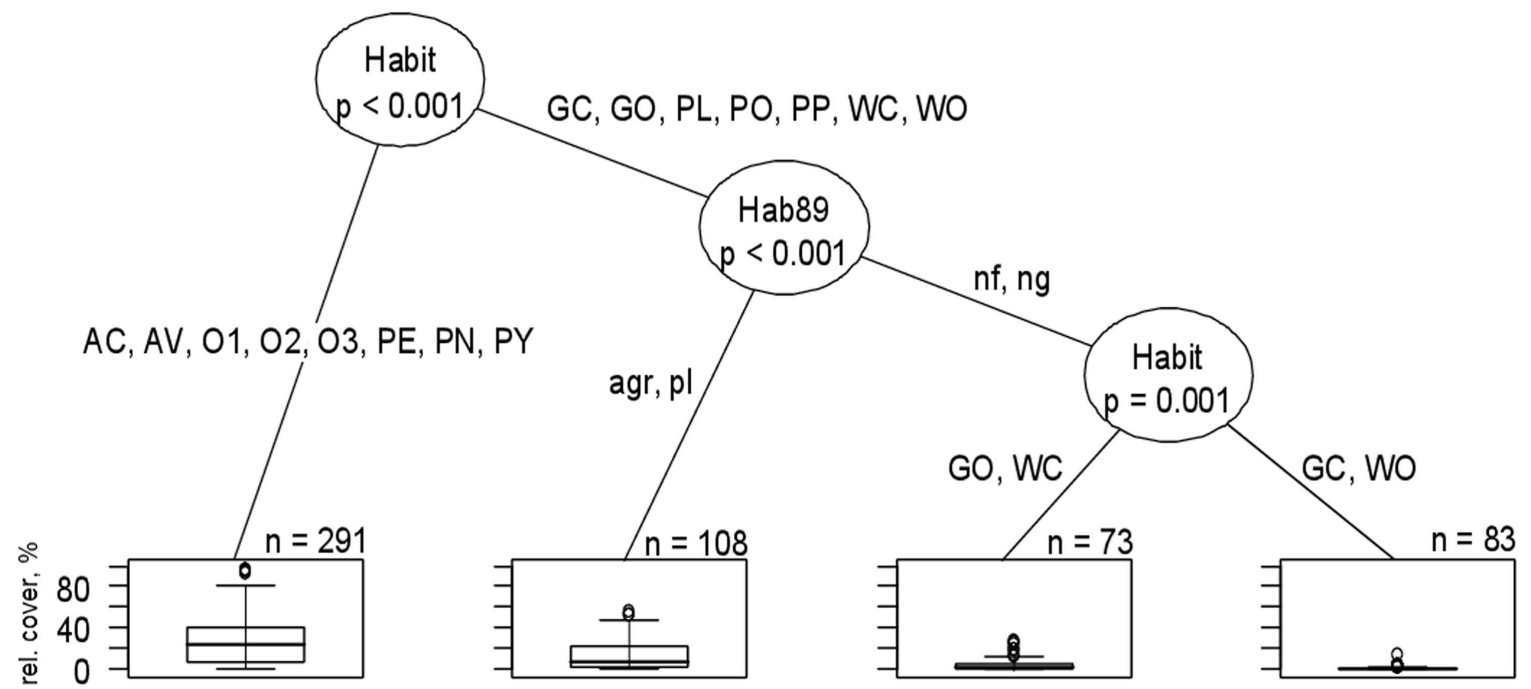

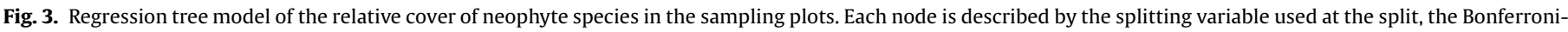

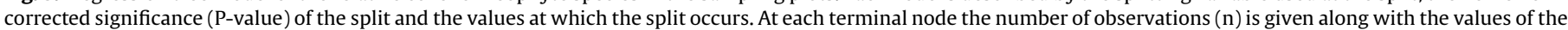

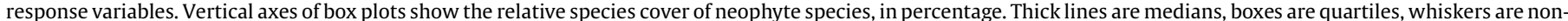

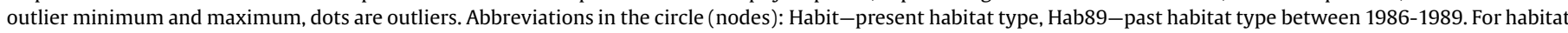
codes see Table 1 .

branch was further split according to the habitat type in 1989. The relative cover of neophyte species was higher (median: 6.05\%) in plots covered by agricultural fields or plantations in 1989 and by pine, black locust or oak plantations in 2008, and lower in plots covered by semi-natural habitats in both dates. Within seminatural habitats neophyte species reached higher levels of cover in closed forests and open grasslands (median: 0.97\%) than in open forests and closed grasslands (median: $0.15 \%$ ).

In the case of the relative cover of annual neophyte species, the regression tree explained $49.4 \%$ of the total variance. The first splitting variable was the present habitat type (Fig. 4). Vineyards and fruit orchards, young old-fields, and young tree plantations had the highest annual neophyte cover, especially where the shrub cover was lower than 5.01\% (median: $26.72 \%$ and $9.62 \%$ for lower and higher shrub cover, on the last two branches, respectively). In the case of other habitats, higher annual neophyte cover (median: $1.14 \%$ ) was found in plots that were agricultural fields or secondary grasslands during the period 1986-1989 (mainly in the present elder old-fields and croplands), than in plots that were seminatural habitats or tree plantations during this period. In these last group of plots the cover of annual neophyte species was negligible.

The regression tree of the relative cover of herbaceous perennial neophytes explained $32.7 \%$ of the total variance. Plots first were classified into three groups according to the habitat type (Fig. 5): (1) the old-fields, native and exotic poplar plantations and young plantations, (2) pine and black locust plantations and (3) other habitats. From the plots of the first group, on the left branch the plots with low tree cover (under 6.01\%) and under warmer climate harboured the highest level of perennial herbaceous neophytes (median: 17.55\%). On the right branch, pine and black locust plantations harboured higher level of herbaceous perennial neophyte species, if the proportion of secondary grassland in the $500 \mathrm{~m}$ radius around the plot is more than $26.77 \%$ (median: $13.62 \%$ ) or the plantation was agricultural area in the period of

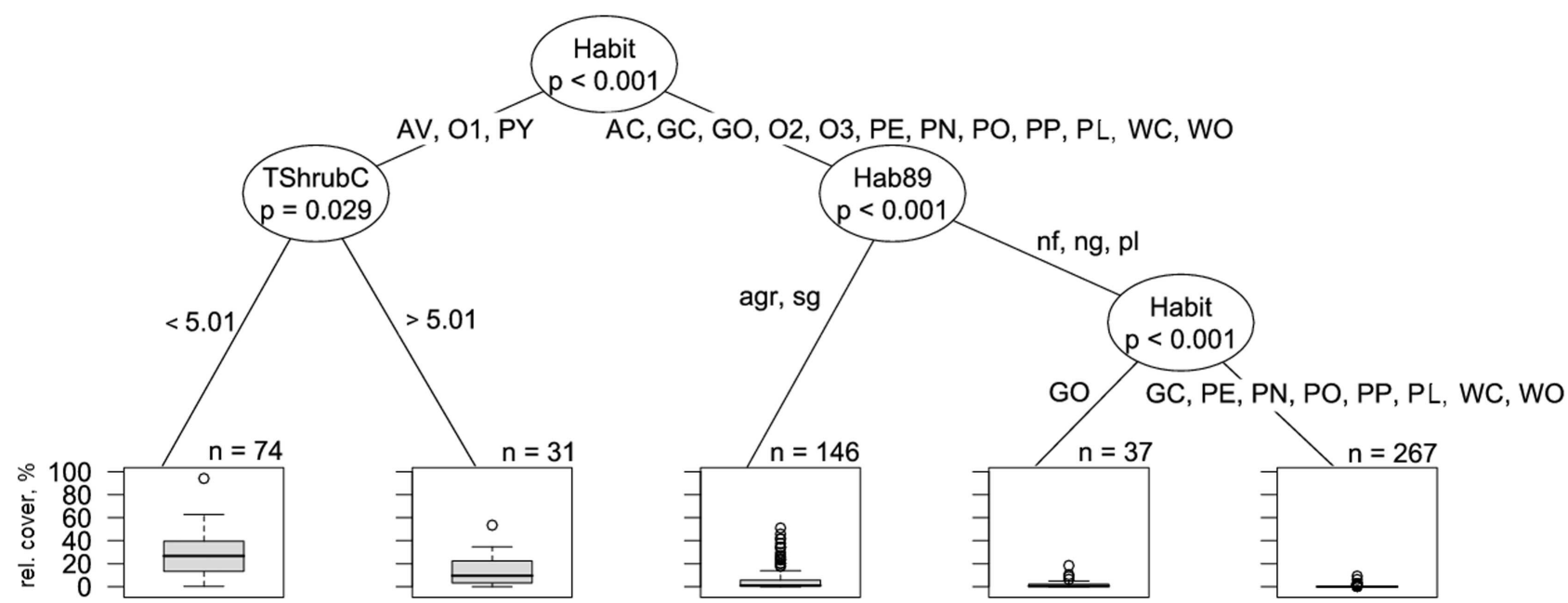

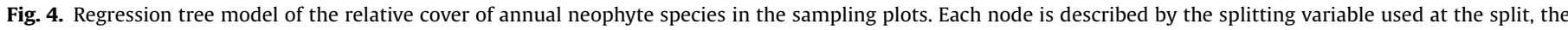

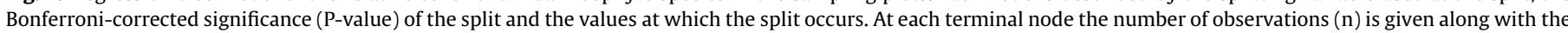

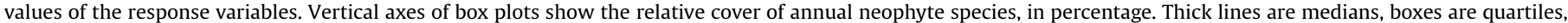

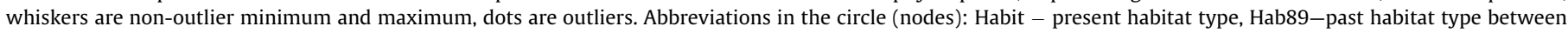
1986-1989, TshrubC-cover of shrubs and trees. For habitat codes see Table 1. 


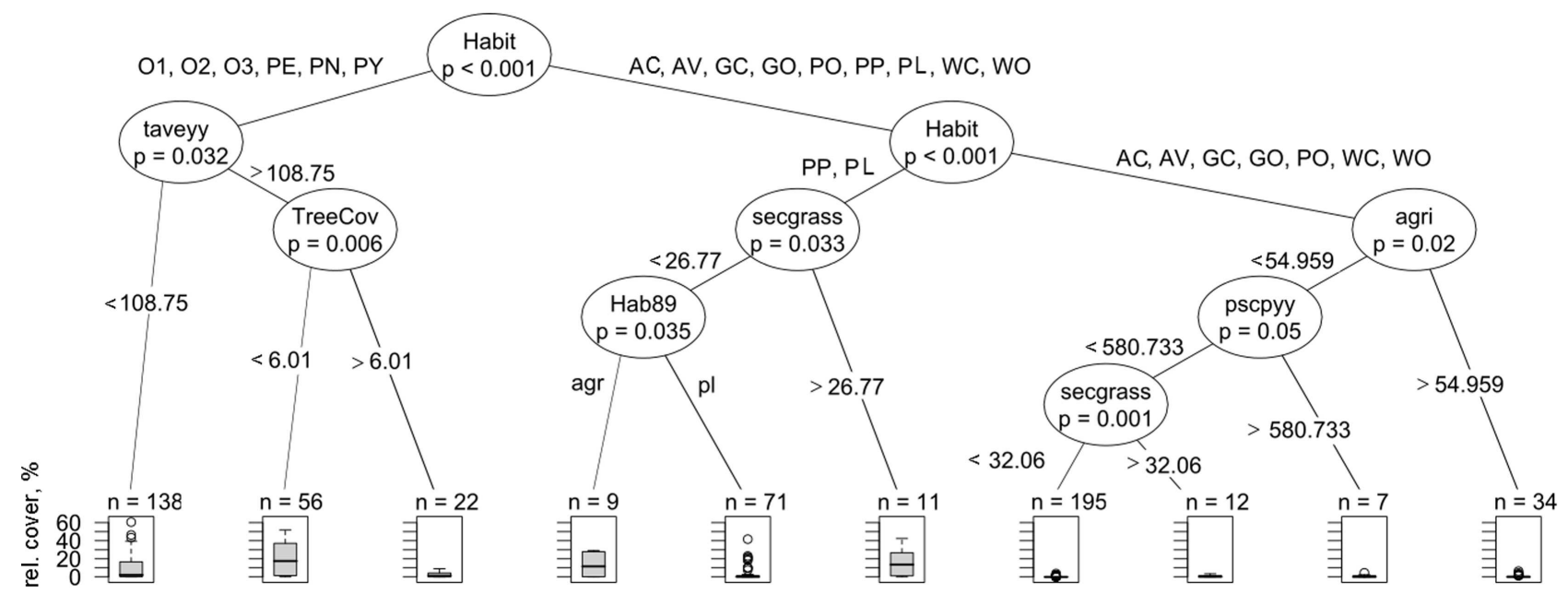

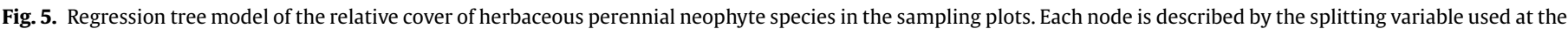

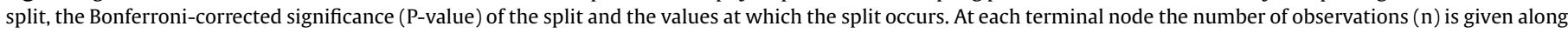

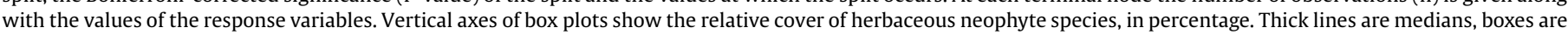

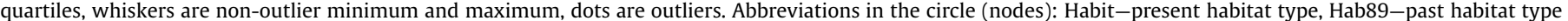

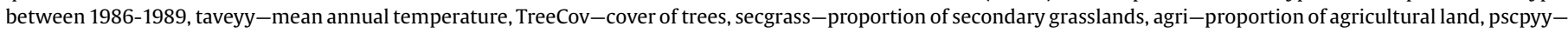
mean annual rainfall. For habitat codes see Table 1.

1986-1989 (median: 11.61\%). In the last group (agricultural fields, semi-natural habitats and oak plantation) the relative cover of herbaceous perennial neophytes is negligible.

The regression tree of the relative cover of woody neophyte species explained $28.5 \%$ of the total variance. The most important predictor variable was again the recent habitat type (Fig. 6). The relative cover of spontaneously occurring woody neophyte species was largest in plots of tree plantations (median: 4.21\%), except for black locust plantations. The black locust plantations were grouped together with semi-natural closed forests (planted and spontaneous presence of neophyte species such as black locust were distinguished). In this group of plots higher cover of woody neophytes (median: 3.92\%) was found if the proportion of plantations in the surrounding of plots was larger (more than $65.5 \%$ ). In the case of non-woody habitats, young plantations and open forests, the cover of woody neophyte species was higher if the plot was semi-natural forest or tree plantation in the 1950s (median: 0.19\%), than if it was agricultural fields or semi-natural grasslands (median: $0.00 \%$ in every case).

\section{Discussion}

\subsection{Determinants of invasion level in the Kiskunság}

The actual level of invasion is the result of the invasion process which is driven by several factors such as environmental conditios, landscape composition and present and past land-use. In our study, the most important factor explaining the level of invasion was the present habitat type. At the intermediate scales, landscape configuration, habitat type and species composition are expected to determine the level of invasion (Milbau et al., 2009). Our results correspond to the findings of Chytrý et al. (2008b), who revealed

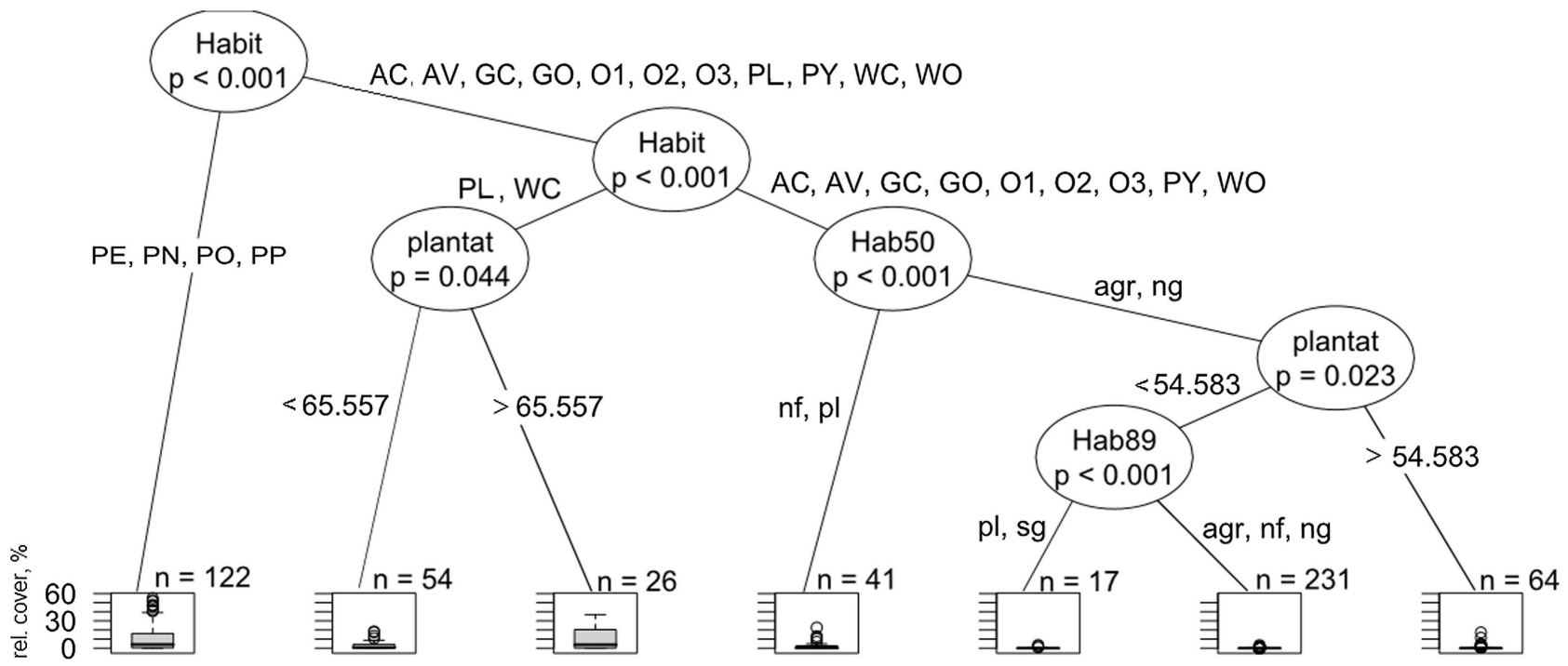

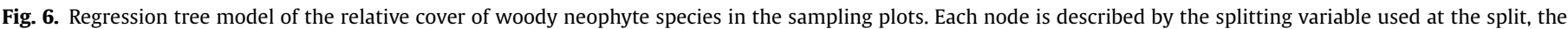

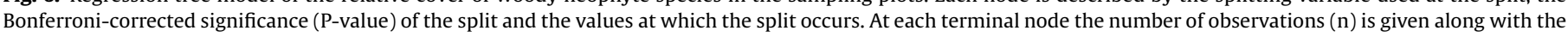

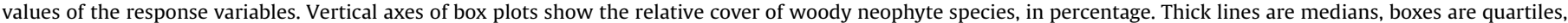

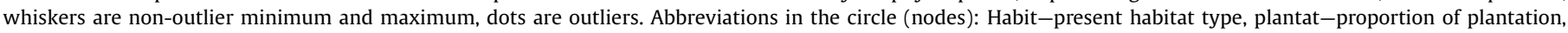
Hab50-past habitat type in 1950, Hab89-past habitat type between 1986-1989. For habitat codes see Table 1. 
that habitat type is the single most important determinant of the level of invasion, probably because habitat type reflects the combination of local abiotic conditions, land-use and disturbance regime (Hobbs, 2000; Vilà et al., 2006).

The second most important factor was past habitat type. Both the long history of human land-use and the changes in the disturbance regime in the past can be responsible for a higher level of invasion (Török et al., 2003; Vilà and Ibáñez, 2011). The Kiskunság region has been exposed to intensive human impacts at least for two millennia. Main land-use changes have been conversion of semi-natural grassland and forest to tree plantation or arable land, arable land conversion to tree plantation and land abandonment enabling the regeneration of grasslands (Biró et al., 2013). Although sand grasslands have high regeneration potential in terms of grassland species richness and cover, even transformation to this habitat type facilitates the invasion and persistence of neophyte species (Albert et al., 2014; Bartha et al., 2008; Csecserits et al., 2011; Szitár and Török, 2008). Since our study demonstrated that historical land-use and land-use changes have considerable impact on invasion, we share the view of Vilà and Ibáñez (2011) that present land-uses might represent an invasion credit to future invasions.

In our study landscape composition played a subordinate role in determining the level of invasion. For example the proportional area of tree plantations within $500 \mathrm{~m}$ around sampling plots exerts influence on the relative cover of woody neophyte species (Fig. 6). The relative species richness of neophytes in agricultural plots increases with increasing distance from arable lands (Fig. 2) probably because of the higher proportion of other land-use types such as plantations or secondary grasslands within the landscape. Agricultural intensification and anthropogenic development (urbanization, transport networks) within a landscape are known to increase invasion (Vilà and Ibáñez, 2011). Current scenarios predict no increase or even decrease in the level of invasion for Eastern Europe due to abandonment of arable land (Chytrý et al., 2012). However tree plantations are rarely considered separately (Martin et al., 2008), which can lead to misleading results when projecting trends for future plant invasions. Our studies suggest that if land conversion from arable land to tree plantation (e.g. woody biofuel plantations) takes place, the level of neophyte invasion, especially by woody species might increase.

We found no relationship between the climatic variables and the level of invasion. Climatic variables are known to influence the invasion process, but mainly at the continental and regional scale (Milbau et al., 2009) where climate varies considerably. Since our study was conducted within the same climatic region, climatic variables did not explain differences in invasion level due to their low variability. Similar trends were found in the case of soil properties. Although in coarser-scale comparisons soil properties generally play an important role in invasion level (e.g. Botta-Dukát, 2008), in our study soil properties had no explanatory power because our focus was on sandy soils with only a limited variability in soil properties.

\subsection{Where are the hot-spots of invasion?}

In the studied region (Kiskunság), besides agricultural habitats, tree plantations are the hot-spots of alien invasion. The mean number of neophyte species found in our plots are relatively high compared to the results of similar analysis (Chytrý et al., 2005; Vilà and Ibáñez, 2007): in the case of agricultural habitats about one quarter of the species are neophytes, where as in the case of plantations only one fifth of the species are neophytes (Fig. 2). Plant invasions are generally facilitated with increasing disturbance levels (Chytrý et al., 2008a, 2008b; González-Moreno et al., 2014; Vilà et al., 2007). The high level of invasion in disturbed habitats is consistent with the theory of fluctuating resource availability (Davis et al., 2000; Shea and Chesson, 2002). At the same time, a more intensive human land-use is also connected to a higher level of propagule pressure as a result of factors such as; weed contaminated seed mixtures, agricultural machinery transporting weed seeds; and direct planting of alien species in tree plantations and orchards (Pinke et al., 2011)

Agricultural habitats are well-known hot-spots of invasion because of the high disturbance level and intensive human landuse (Pinke et al., 2011). However, tree-plantations are less studied in terms of plant invasion (but see: Bremer and Farley, 2010). In our case there could be two reasons for the high invasion levels found in tree plantations: (1) the technology of the plantation establishment and (2) that the presence and abundance of forest species is very low (Levine and D'Antonio, 1999) due to the small size of the regional forest species pool (Molnár et al., 1998; Magyari et al., 2010; Molnár et al., 2012). Plantations are created after felling, forest clearing and soil preparation or after ploughing of arable lands. Forestry practice also includes yearly weeding and ploughing between rows in the first years. This results in levels of invasion comparable to arable fields, especially in the case of young plantations. Although during the development of a closed forest canopy, trees outcompete light-requiring annual weeds, woody neophytes are not replaced by native species, presumably because of the small size of the natural species pool. The forest elements of the original forest steppe almost completely disappeared by the 18th century (Molnár et al., 2012) and according to a recent habitat mapping of Hungary, only 1200 ha of closed and 290 ha of open lowland steppe oak woodlands remained in the Great Hungarian Plain (Bölöni et al., 2008). While ca 186000 ha of the county BácsKiskun (larger part of the Kiskunság region) was covered by forest in 2012, often planted with alien tree species (KSH, 2013). This means that the vast majority of woodlands in the region are tree plantations that are probably an important source of propagules of neophyte species.

The third group of habitats with high invasion levels in our study are old-fields. Secondary grasslands developed on old-fields are in a transitional position between heavily managed and seminatural habitats. The decreasing invasion level with the increasing time after abandonment in the old-fields of the region has already been demonstrated and its reason discussed by Csecserits et al. (2011).

Semi-natural grasslands and woodlands are the least infected by invasive species (Figs. 2 and 3). Among them, closed forests are the most invaded, based on the relative number of neophyte species and the cover of woody neophytes. There could be two different, but closely related reasons for this. First, the groundwater table has decreased by $2-4 \mathrm{~m}$ in the last four decades in the region (Biró et al., 2013; Pálfai, 1993; Szilágyi and Vörösmarty, 1997), and the most water-dependent closed forests are degrading, which provides a favourable condition for plant invasion. At the same time, the extent of tree plantations has increased in the last 100 years (Biró et al., 2013), and the native Quercus robur was often replaced by nonindigenous trees that tolerate water shortage. Thus, the remnants of semi-natural closed forests are surrounded by native and non-native tree plantations, and therefore are under continuous propagule pressure of alien species.

\subsection{Invasion of neophytes with different life forms}

Life form can be among the most powerful attributes explaining patterns of plant invasion (Thuiller et al., 2006). Splitting neophytes into three groups according to their life form revealed considerable differences in their affinity to habitat types. As expected, habitats that are recently or annually disturbed harbour the largest relative cover of annual neophytes. Beside agricultural 
habitats, young old-fields and young (1-3 years old) tree plantations are among the most infected habitats. Annual species with short life-cycle and persistent seedbank are adapted to frequent disturbance (Gassó et al., 2012; Pinke et al., 2011). If disturbance ceases (e.g. in the case of secondary grassland development), or/and canopy cover increases, these species will be outcompeted in the course of time (Grime, 1979), but past agricultural use is reflected in the cover of annual neophytes even after decades. One of the most common annual neophyte species of the studied region is the common ragweed (Ambrosia artemisiifolia), which because of its allergic pollen, is one of the most noxious annual invaders, both locally and in Europe (DAISIE, 2009; Pinke et al., 2011). The presence of ragweed is connected to agricultural cultivation and soil disturbance, but its abundance quickly decreases with the development of secondary grasslands (App.1) (Csecserits et al., 2011, 2012).

In the case of perennial herbaceous neophytes, besides the present habitat type, the past habitat and landscape context proved to be important in determining the level of invasion. We found larger cover of perennial herbaceous neophytes in plots that were intensively used by human in the past, such as abandoned agricultural fields and tree plantations. Previous disturbance creates open space for the establishment of neophyte species, and the cessation of cultivations enables perennial neophytes to spread. In the studied dry, sandy region not all plantations can develop fully closed canopy, therefore species such as milkweed (Asclepias syriaca) and goldenrod (Solidago canadensis and gigantea) can survive in the herb-layer (App.1). In a large-scale survey, Botta-Dukát (2008) found that open sand grasslands are the second most invaded habitats, and milkweed occurred in $75 \%$ of these grasslands. A future increase in the extent of tree plantations that can host milkweed is expected to further degrade the state of semi-natural open sand grasslands.

In contrast to annual neophytes, woody neophytes that were originally introduced for silviculture or horticulture can invade tree plantations and semi-natural forests and are underrepresented in open agricultural habitats (Gassó et al., 2012; Thuiller et al., 2006). Several woody neophytes, e.g. Padus serotina are successful invaders in forests because they form a long-living, shade-tolerant sapling-bank (Closset-Kopp et al., 2007). In our case, not only the current habitat type, but also the area of tree plantations in the surrounding landscape and the past forest practices influence the level of invasion by woody neophytes. There are two reasons for this: the establishment technique of plantation in the region (ploughing before planting, see above), and the use of non-native species in forestry, which can behave as invasive species (DAISIE, 2009; Bartha et al., 2012). For instance, black locust is successful both in generative and vegetative spreading, and its stands host other neophyte species, which means that its plantations represent strong propagule pressure for semi-natural woodlands.

Several woody neophytes, such as Ailanthus altissima, Celtis occidentalis, Padus serotina, Robinia pseudoacacia can escape from plantations and can invade the dry grasslands of both secondary and primary origin (Török et al., 2003; Botta-Dukát, 2008). Nature conservation authorities endeavour to eliminate invasive species from semi-natural habitats (Mihály and Botta-Dukát, 2004), but the current tree plantation practices (ploughing before plantation, use of neophyte and even invasive species such as black locust) in the neighbourhood of conservation areas make this a big challenge (e.g. Verő, 2011).

\subsection{Conclusions and implications}

Our study emphasizes that habitat type is the most important determinant of invasion level, and therefore present and past human land-use is a key factor in the establishment and spread of alien species. Tree plantations are hot-spots of alien invasion hosting numerous alien species with considerable coverage. The presence of plantations increases the level of invasion in other habitats since it entails an increased propagule pressure that threatens neighbouring habitats, especially fragments of the (semi-) natural vegetation.

Since human land-use plays a key role in forming the actual level of invasion, land-users have many possibilities to control the invasion of alien plant species (Cole et al., 2007). A number of connected strategies could be applied to prevent or hinder the alien plant invasion. Therefore we suggest

- limiting the amount of ecosystem disturbance, especially in semi-natural habitats to prevent establishment of invasive plants,

- restricting the amount of new plantations around the remnants of semi-natural vegetation within a radius of at least $500 \mathrm{~m}$,

- avoiding the use of invasive neophyte species for tree plantation especially within at least $1000 \mathrm{~m}$ around the remnants of seminatural vegetation,

- reconsidering plantation techniques in order to limit the disturbance and minimize time in which invasive neophyte species can establish

- avoiding frequent habitat conversion by long-term land-use planning,

- and restricting habitat conversion from primary and secondary grassland into arable land or tree plantation.

\section{Author contributions}

MH, GyKD and TR conceived the study, ACs, MH, GyKD, BL, GÓ, TR and KSz collected data on field, ACs, MH, GÓ, TR and KSz, performed the GIS database, ACs and KSz made the GIS analysis, ACs and ZBD computed statistical analysis, ACs and MH wrote the paper and all authors interpreted the results and commented on the manuscript.

\section{Acknowledgements}

This work was supported by the grants No. NKFP6/013/2005 and OTKA-NKTH CNK80140.

We would like to thank the several surveyors for field data collection. We also thank Eszter Lelleiné-Kovács the GIS work, Miles R. Marshall for language revision and two referees for valuable comments.

\section{Appendix A. Supplementary data}

Supplementary data associated with this article can be found, in the online version, at http://dx.doi.org/10.1016/j.agee.2016.03.024.

\section{References}

AGROTOPO, 1994. a Internet]Spatial Soil Information System. RISSAC HAS, Budapest. (cited 2011.09.11) http://www.mta-taki.hu/hu/osztalyok/gis-labor/agrotopo.

Albert, Á.J., Kelemen, A., Valkó, O., Miglécz, T., Csecserits, A., Rédei, T., Török, P., 2014. Secondary succession in sandy old-fields: a promising example of spontaneous grassland recovery. Appl. Veg. Sci. 17, 214-224.

Bölöni, J., Molnár, Z., Biró, M., Horváth, F., 2008. Distribution of the (semi-) natural habitats in Hungary II: Woodlands and shrublands. Acta Botanica Hungarica 50, 107-148.

Balogh, L., Dancza, I., Király, G., 2004. A magyarországi neofitonok időszerủ jegyzéke és besorolásuk inváziós szempontból (Actual list of neophytes in Hungary and their classification according to their success). In: Mihály, B., Botta-Dukát, Z (Eds.), Özönnövények (Invasive Plants). Természetbúvár Alapítvány Kiadó, Budapest, Hungary, pp. 61-92. 
Bartha, S., Molnár, Z., Fekete, G., 2008. Patch dynamics in sand grasslands: connecting primary and secondary succession. In: Kovács-Láng, E., Molnár, E., Kröel-Dulay, Gy., Barabás, S. (Eds.), The KISKUN LTER, long-term Ecological Research in the Kiskunság, Hungary. Vácrátót. Institute of Ecology and Botany, HAS, 37-40.

Bartha, D., Csiszár, Á., Zagyvai, G., Zsigmond, V., 2012. Fehér akác (Robinia pseudoacacia L.). In: Csiszár, Á. (Ed.), Inváziós növényfajok Magyarországon (Invasive Plant Species in Hungary). Nyugat-Magyarországi Egyetem Kiadó, Sopron, pp. 127-132.

Biró, M., Szitár, K., Horváth, F., Bagi, I., Molnár, Z., 2013. Detection of long-term landscape changes and trajectories in a Pannonian sand region: comparing land-cover and habitat-based approaches at two spatial scales. Commun. Ecol. 14, 219-230.

Bjornstad, O.N., Falck, W., 2001. Nonparametric spatial covariance functions: estimation and testing. Environ. Ecol. Stat. 8, 53-70.

Bjornstad, O.N., 2013. ncf: spatial nonparametric covariance functions. R package version 1,1-5. http://CRAN.R-project.org/package=ncf.

Botta-Dukát, Z., 2008. Invasion of alien species to Hungarian (semi-) natural habitats. Acta Botanica Hungarica 50, 219-227.

Breiman, L., Freidman, J.H., Olshen, R.A., Stone, C.J., 1984. Classification and Regression Trees. Wadsworth, Belmont.

Bremer, L.L., Farley, K.A., 2010. Does plantation forestry restore biodiversity or create green deserts?: A synthesis of the effects of land-use transitions on plant species richness. Biodivers. Conserv. 19, 3893-3915.

Catford, J.A., Vesk, P.A., Richardson, D.M., Pyšek, P., 2012. Quantifying levels of biological invasion: towards the objective classification of invaded and invasible ecosystems. Global Change Biol. 18, 44-62.

Chytrý, M., Pyšek, P., Tichý, L., Knollová, I., Danihelka, J., 2005. Invasion by alien plants in the Czech Republic: a quantitative assessment across habitats. Preslia 77, 339-354.

Chytrý, M., Jarošik, V., Pyšek, P., Hájek, O., Knollová, I., Tichý, L., Danihelka, J., 2008a. Separating habitat invisibility by alien plants from the actual level of invasion. Ecology 89, 1541-1553.

Chytrý, M., Maskell, L.G., Pino, J., Pyšek, P., Vilà, M., Font, X., Smart, S.M., 2008b. Habitat invasion by alien plants: a quantitative comparison among the Mediterranean, subcontinental and oceanic regions of Europe. J. Appl. Ecol. 45, 448-458.

Chytrý, M., Pyšek, P., Wild, J., Pino, J., Maskell, L.G., Vilà, M., 2009. European map of alien plant invasions based on the quantitative assessment across habitats. Divers. Distri. 15, 98-107.

Chytrý, M., Wild, J., Pyšek, P., Jarošík, V., Dendoncker, N., Reginster, I., Settele, J., 2012. Projecting trends in plant invasions in Europe under different scenarios of future land-use change. Global Ecol. Biogeol. 21, 75-87.

Closset-Kopp, D., Chabrerie, O., Valentin, B., Delachapelle, H., Decocq, G., 2007. When Oskar meets Alice: does a lack of trade-off in r/K-strategies make Prunus serotina a successful invader of European forests? For. Ecol. Manage. 247, 120-130.

Cole, D.E., King, J.R., Oyarzun, D.A., Dietzler, T.H., McClay, A.S., 2007. Experiences with invasive plant management and ecology in Alberta. Can J. Plant Sci. 87 (5), 1013-1022.

Crawley, M.J., 2007. The R Book. John Wiley \& Sons, Ltd., Chichester.

Csatári, B., Farkas, J., 2008. Agrarian and rural development in Hungary, 1990-2005 In: Bańsky, J., Bednarek, M. (Eds.), Contemporary Changes of Agriculture in EastCentral Europe. Polish Academy of Sciences, Institute of Geography and Spatial Organization, Polish Geographical Society, Warsaw. (Rural Studies 15), pp. 147-164.

Csecserits, A., Czúcz, B., Halassy, M., Kröel-Dulay, Gy., Rédei, T., Szabó, R., Szitár, K., Török, K., 2011. Regeneration of sandy old-fields in the forest steppe region of Hungary. Plant Biosyst. 145, 715-729.

Csecserits, A., Kröel-Dulay, Gy., Szitár, K., Botta-Dukát, Z., Kazinczi, G., Lehoczky, É. 2012. Az ürömlevelủ parlagfü (Ambrosia artemisiifolia L.) eredményes védekezést meghatározó biológiai tulajdonságai. In: Kazinczi, G., Novák, R. (Eds.), A parlagfủ visszaszorításának integrált módszerei. Gyommentes Környezetért Alapítvány, Budapest, pp. 6-19.

DAISIE, 2009. Handbook of Alien Species in Europe. Springer, Dordrecht (ISBN 978 1-4020-8279-5).

Davis, M.A., Grime, J.P., Thompson, K., 2000. Fluctuating resources in plant communities: a general theory of invasibility. J. Ecol. 88, 528-534.

ESRI, 2006. ArcGIS Vers. 9.2. Environmental Systems Research Institute Inc. Redlands, CA.

Fekete, G., Molnár, Z., Magyari, E., Somodi, I., Varga, Z., 2014. A new framework for understanding Pannonian vegetation patterns: regularities, deviations and uniqueness. Commun. Ecol. 15 (1), 12-26.

Gassó, N., Pino, J., Font, X., Vilà, M., 2012. Regional context affects native and alien plant species richness across habitat types. Appl. Veg. Sci. 15 (1), 4-13.

González-Moreno, P., Diez, J.M., Ibáñez, I., Font, X., Vilà, M., 2014. Plant invasions are context-dependent: multiscale effects of climate, human activity and habitat. Divers. Dist. 20, 720-731.

Grime, J.P., 1979. Plant Strategies and Vegetation Processes. Wiley, New York. HMS (Hungarian Meteorological Service), 2001. Magyarország Éghajlati Atlasza (Climate Atlas of Hungary). Hungarian Meteorological Service, Budapest.

Hejda, M., Pyšek, P., Jarošík, V., 2009. Impact of invasive plants on the species richness, diversity and composition of invaded communities. J. Ecol. 97, 393-403.

Hijmans, R.J., Cameron, S.E., Parra, J.L., Jones, P.G., Jarvis, A., 2005. Very high resolution interpolated climate surfaces for global land areas. Int. J. Climatol. 25, 1965-1978.
Hobbs, R.J., 2000. Land-use changes and invasion. In: Mooney, H.A., Hobbs, R.J. (Eds.), Invasive Species in a Changing World. Island Press, Washington, D.C, pp. 55-64.

Hothorn, T., Hornik, K., Zeileis, A., 2006. Unbiased recursive partitioning: a conditional inference framework. J. Comput. Graph Stat. 15, 651-674.

Jauni, M., Hyvönen, T., 2010. Invasion level of alien plants in semi-natural agricultural habitats in boreal region. Agric. Ecosyst. Environ. 138, 109-115.

KSH (Hungarian Central Statistical Office, HCSO), 2013. Az erdőgazdálkodás jellemzői (Characteristics of the silviculture). Statisztikai Tükör 7 (95), 1-6.

Király, G., 2009. Új Magyar Füvészkönyv. Magyarország hajtásos növényei. Határozókulcsok. (New Hungarian Herbal. The Vascular Plants of Hungary. Identification keys). Aggtelek National Park Directorate, Jósvafő (616 p.).

Levine, J.M., D'Antonio, C.M., 1999. Elton revisited: a review of evidence linking diversity and invasibility. Oikos 87, 15-26.

Magyari, E.K., Chapman, J.C., Passmore, D.G., Allen, J.R.M., Huntley, J.P., Huntley, B. 2010. Holocene persistence of wooded steppe in the Great Hungarian Plain. J. Biogeogr. 37, 915-935.

Martin, P.H., Canham, C.D., Marks, P.L., 2008. Why forests appear resistant to exotic plant invasions: intentional introductions stand dynamics, and the role of shade tolerance. Front. Ecol. Environ. 7, 142-149.

Mihály, B., Botta-Dukát, Z. (Eds.), 2004. Özönnövények (Invasive plants). Természetbúvár Alapítvány Kiadó, Budapest, Hungary, pp. 408.

Milbau, A., Stout, J.C., Graae, B.J., Nijs, I., 2009. A hierarchical framework for integrating invasibility experiments incorporating different factors and spatial scales. Biol. Inv. 11, 941-950.

Molnár, Z., Kirby, K.J., Watkins, C., 1998. Interpreting present vegetation features by landscape historical data: an example from a woodland-grassland mosaic landscape (Nagykörös wood, Kiskunság, Hungary). The Ecological History of European Forests: Based on Presentations Given at the International Conference on Advances in Forest and Woodland History, Held at the University of Nottingham in September 1996. CAB INTERNATIONAL pp. 241-263.

Molnár, Z., Biró, M., Bartha, S., Fekete, G., 2012. Past trends, present state and future prospects of Hungarian forest-steppes. Eurasian Steppes. Ecological Problems and Livelihoods in a Changing World. Springer, Netherlands, pp. 209-252.

Pálfai, I., 1993. Talajvízsüllyedés a Duna-Tisza közén. Vízügyi Közlemények 75, 431-434.

Pinke, G., Karácsony, P., Czúcz, B., Botta-Dukát, Z., 2011. Environmental and land-use variables determining the abundance of Ambrosia artemisiifolia in arable fields in Hungary. Preslia 83, 219-235.

Pyšek, P., Chytrý, M., 2014. Habitat invasion research: where vegetation science and invasion ecology meet. J. Veg. Sci. 25, 1181-1187.

Pyšek, P., Jarošík, V., 2005. Residence time determines the distribution of alien plants. In: Inderjit, S. (Ed.), Invasive Plants: Agricultural and Ecological Aspects. Birkhauser, Verlag, Basel, Switzerland, pp. 77-96.

Pyšek, P., Richardson, D.M., Rejmánek, M., Webster, G., Williamson, M., Kirschner, J., 2004. Alien plants in checklists and floras: towards a better communication between taxonomy and ecologists. Taxon 53, 131-143.

Pyšek, P., Bacher, S., Chytrý, M., Jarošík, V., Wild, J., Celesti-Grapow, L., Gassó, N., Kenis, M., Lambdon, P.W., Nentwig, W., Pergl, J., Roques, A., Sádlo, J., Solarz, W., Vilà, M., Hulme, P.E., 2010. Contrasting patterns in the invasions of European terrestrial and freshwater habitats by alien plants, insects and vertebrates. Global Ecol. Biogeogr. 19, 317-331.

Pyšek, P. 1995. On the terminology used in plant invasion studies. In: Pyšek, P., Prach, K., Rejmánek, M., Wade, M. (Eds.), Plant Invasions: General Aspects and Special Problems. SPB Academic Publishing, Amsterdam, pp. 71-81.

R Core Team, 2014. R: A Language and Environment for Statistical Computing. R Foundation for Statistical Computing, Vienna, Austria. http://www.R-project. org/.

Rédei, T., Kröel-Dulay, Gy., Barabás, S., Lellei-Kovács, E., Szabó, R., Török, K., 2008. A network of long-term ecological and socio-economic research sites to study the effects of 1 and use change. In: Kovács-Láng, E., Molnár, E., Kröel-Dulay, Gy., Barabás, S. (Eds.), The KISKUN LTER: Long-Term Ecological Research in the Kiskunság, Hungary. IEB HAS, Vácrátót, pp. 15-19.

Rédei, T., Csecserits, A., Barabás, S., Halassy, M., Kröel-Dulay, Gy., Lelleiné Kovács, E., Ónodi, G., Pándi, I., Somay, L., Szabó, R., Szitár, K., Török, K., 2011. Tájhasználat és biodiverzitás kapcsolatának regionális léptékủ vizsgálata a Kiskunságban: a Kiskun_LTER mintaterület-hálózat bemutatása. (Observing the interactions of landscape use and biodiversity on a regional scale in Kiskunság, Hungary: Introducing the sample sites of KISKUN LTER Network. In: VerÄ, Gy. (Ed.), Természetvédelem és kutatás a Duna-Tisza közi homokhátságon (Nature conservation and researches on the Sandbridge of the Danube-Tisza Interfluve.). Rosalia 6. Duna-Ipoly Nemzeti Park Igazgatóság, Budapest, pp. 423-445.

Rédei, T., Szitár, K., Czúcz, B., Barabás, S., Lellei-Kovács, E., Pándi, I., Somay, L., Csecserits, A., 2014. Weak evidence of long-term extinction debt in Pannonian dry sand grasslands. Agric. Ecosyst. Environ. 182, 137-143.

Richardson, D.M., Pyšek, P., 2006. Plant invasions: merging the concept of species invasiveness and community invisibility. Prog. Phys. Geogr. 30, 409-431.

Rouget, M., Richardson, D.M., 2003. Inferring process from pattern in plant invasions: a semimechanistic model incorporating propagule pressure and environmental factors. Am. Naturalist 162, 713-724.

Sala, O.E., Chapin, F.S., Armesto, J.J., Berlow, E., Bloomfield, J., Dirzo, R., HuberSanwald, E., Huenneke, L.F., Jackson, R.B., Kinzig, A., Leemans, R., Lodge, D.M. Mooney, H.A., Oesterheld, M., Poff, N.L., Sykes, M.T., Walker, B.H., Wall, D.H., 2000. Global biodiversity scenarios for the year 2100 . Science $287,1770-1774$

Shea, K., Chesson, P., 2002. Community ecology theory as a framework for biological invasions. Trends Ecol. Evolut. 17, 170-176. 
Somodi, I., Virágh, K., Székely, B., Zimmermann, N.E., 2010. Changes in predictor influence with time and with vegetation type identity in a post-abandonment situation. Basic Appl. Ecol. 11, 225-233.

Szilágyi, J., Vörösmarty, C.J., 1997. Modelling unconfined aquifer level reductions in the area between the Danube and Tisza rivers in Hungary. J. Hydrol. Hydromech. $45,328-347$.

Szitár, K., Török, K., 2008. Short-term effects of herbicide treatment on the vegetation of semiarid sandy oldfields invaded by Asclepias syriaca L.. Extended abstract in the Proceedings of the 6th European Conference on Ecological Restoration 8-12.

Török, K., Botta-Dukát, Z., Dancza, I., Németh, I., Kiss, J., Mihály, B., Magyar, D., 2003 Invasion gateways and corridors in the Carpathian Basin: biological invasions in Hungary. Biol. Invasions 5, 349-356.

Thomas, S.M., Moloney, K.A., 2015. Combining the effects of surrounding land-use and propagule pressure to predict the distribution of an invasive plant. Biol. Invasions 17, 477-495.

Thuiller, W., Richardson, D.M., Rouget, M., Proches, S., Wilson, J.R., 2006. Interactions between environment, species traits, and human uses describe patterns of plant invasions. Ecology 87, 1755-1769.

Usio, N., Nakajima, H., Kamiyama, R., Wakana, I., Hiruta, S., Takamura, N., 2006. Predicting the distribution of invasive crayfish (Pacifastacus leniusculus) in a Kusiro Moor marsh (Japan) using classification and regression trees. Ecol. Res. 21, 271-277.

Verő, Gy., 2011. LIFE-Nature program a "Nagykőrősi pusztai tölgyesek" Natura 2000 területen 2006-2011. In: Verö, Gy. (Ed.), Természetvédelem és kutatás a Duna-
Tisza közi Homokhátságon (Nature Conservation and Researches on the Sandridge of the Danube-Tisza Interfluve). Rosalia 6. Duna-Ipoly Nemzeti Park Igazgatóság, Budapest, pp. 13-36.

Vicente, J.R., Pereira, H.M., Randin, C.F., Goncalves, J., Lomba, A., Alves, P., Honrado, J., 2014. Environment and dispersal paths override life strategies and residence time in determining regional patterns of invasion by alien plants. Perspect. Plant Ecol. 16, 1-10.

Vilà, M., Ibáñez, I., 2011. Plant invasions in the landscape. Landscape Ecol. 26, 461-472.

Vilà, M., Pino, J., Font, X., 2007. Regional assessment of plant invasions across different habitat types. J. Veg. Sci. 18, 35-42.

Vilà, M., Basnou, C., Pyšek, P., Josefsson, M., Genovesi, P., Gollasch, S., Hulme, P.E., 2009. How well do we understand the impacts of alien species on ecosystem services? A pan-European, cross-taxa assessment. Front. Ecol. Environ. 8, 135-144.

Vilà, M., Corbin, J.D., Dukes, J.S., Pino, J., Simth, S.D., 2006. Linking plant invasion to global environmental change. In: Canadell, J., Pataki, D., Pielka, L. (Eds.), Terrestrial Ecosystems in a Changing World. Springer, Berlin, pp. 93-102.

Walter, J., Essl, F., Englisch, T., Kiehn, M., 2005. Neophytes in Austria: habitat preferences and ecological effects. Neobiota 6, 13-25.

Zólyomi, B., 1974. Natürliche Vegetation. Natural Vegetation. Végétation Naturelle. Estestvennaja Rastitelnost. (Ungarischer Teil). In: Niklfeld, H. (Ed.), Atlas der Donaulander No. 171. Österreichisches Ost und Südosteuropa Institut, Wien. 